\title{
Evaluation of the Anti-cancer and Biological Effects of Boric Acid on Colon Cancer Cell Line
}

\section{Kolon Kanseri Hücrelerinde Borik Asidin Anti-kanser ve Biyolojik Etkilerinin Değerlendirilmesi}

\author{
(D) Ayşe Çiğel ${ }^{1}$, (D) Mehmet Dinçer Bilgin², (D) Rauf Onur Ek ${ }^{1}$ \\ ${ }^{1}$ Aydın Adnan Menderes University Faculty of Medicine, Department of Physiology, Aydın, Turkey \\ ${ }^{2}$ Aydın Adnan Menderes University Faculty of Medicine, Department of Biophysics, Aydın, Turkey
}

Keywords

Boric acid, colon cancer, Caco-2 cell line, Caspase-3, BCL-2

Anahtar Kelimeler

Borik asit, kolon kanseri, Caco-2 hücreleri, Capase-3, BCL-2

Received/Geliş Tarihi : 15.10 .2020

Accepted/Kabul Tarihi : 24.10.2020

doi:10.4274/meandros.galenos.2020.82246

Address for Correspondence/Yazışma Adresi: Rauf Onur Ek Prof. Dr.,

Aydın Adnan Menderes University Faculty of Medicine, Department of Physiology, Aydın, Turkey

Phone : +905424578606

E-mail : roek@adu.edu.tr

ORCID ID: orcid.org/0000-0003-3923-0156

(C) Meandros Medical and Dental Journal, Published by Galenos Publishing House.

This is article distributed under the terms of the Creative Commons Attribution NonCommercial 4.0

International Licence (CC BY-NC 4.0).

\begin{abstract}
Objective: The role of boron in biology includes the coordinated regulation of gene expression as well as the growth and proliferation of all living organisms. Boric acid is known to regulate the proliferation of cancer cells. Colon cancer is among the types of cancer with a high rate of mortality in both men and women. The aim of this study is to evaluate the effects of boric acid (the dominant of boron in plasma) on Caco-2 colorectal cancer cell line.

Materials and Methods: Firstly, the cytotoxic effect of boric acid (0 to $1 \mathrm{mM}$ ) on Caco-2 human colon cancer cells was determined and the expressions of Caspase- 3 and BCL-2 were evaluated using Western Blot and sodium dodecyl sulphatepolyacrylamide gel electrophoresis analysis.

Results: Our results showed that boric acid inhibits the proliferation Caco-2 cancer cells in a dose dependent manner. We also demonstrated that BCL-2 protein expression decreased with increasing concentrations of boric acid.

Conclusion: This is the first study that demonstrates the anti-cancer effects of boric acid against Caco-2 cancer cell line. Further studies using advanced molecular techniques are needed to precisely explain the anti-cancer mechanisms of boric acid.
\end{abstract}

Öz

Amaç: Borun biyolojideki rolü, gen ekspresyonunun koordineli düzenlenmesini ve tüm canlı organizmaların büyümesini ve çoğalmasını içerir. Borik asidin kanser hücrelerinin çoğalmasını düzenlediği bilinmektedir. Kolon kanseri, erkeklerde ve kadınlarda yüksek mortaliteye sahip kanser türleri arasındadır. Bu çalışmanın amacı, borik asidin plazmada formu olan borik asidin Caco-2 kolorektal kanser hücreleri üzerindeki etkilerini değerlendirmektir.

Gereç ve Yöntemler: İlk olarak, Caco-2 insan kolon kanseri hücrelerinde borik asidin (0 ila $1 \mathrm{mM}$ ) hücre proliferasyonuna aktivitesini belirlenmiş daha sonra ve Western Blot ve SDS PAGE analizi kullanılarak Caspase-3 ve BCL-2 protein düzeyleri değerlendirilmiştir.

Bulgular: Sonuçlarımız, borik asidin Caco-2 kanser hücrelerinin çoğalmasını doza bağımlı bir şekilde inhibe ettiğini göstermiştir. Ayrıca, borik asit konsantrasyonu arttıkça BCL-2 protein ekspresyonunun azalttığı saptanmıştır.

Sonuç: Bu araştırma borik asidin Caco-2 kanser hücrelerine karşı anti-kanser etkilerini gösteren ilk çalışmadır. Borik asidin anti-kanser mekanizmasını açıklamak için ileri moleküler teknikleri kullanan çalışmalara ihtiyaç vardır. 


\section{Introduction}

Cancer is a public health problem that is growing every day around the world and colon cancer is one of the types of cancer that affects both sexes. It ranks second in frequency in women and third in men, according to 2018 data from the American Cancer Institute. 1.8 million new colon cancer patients were reported in 2018. Although chemotherapy, surgery, and radiotherapy treatment options are used extensively in the treatment of colon cancer, there are difficulties in its treatment due to delayed diagnosis, spread of metastases, and recurrence after surgery $(1,2)$. For these reasons, new treatment models are needed in the treatment of colon cancer.

Boron is one of the trace elements necessary for living organisms commonly found in nature in the form of boric acid and borax, which can bind with high affinity to the oxygen molecule $(3,4)$. Boric acid is a dissolved state of boron element in water and is involved in many physiological and biochemical processes in the body with its antioxidant and anticancer properties, passing quickly into the bloodstream after dietary intake (5-7).

The effects of boron in anti-oxidant defense mechanism is that it reduces the activity of enzymes responsible for inflammation and inhibits the proliferation of cancer cells, which can lead to clinical use of boron-containing compounds (8-10). In 2019, Albuz et al. (11) demonstrated that boron oxide $\left(\mathrm{B}_{2} \mathrm{O}_{3}\right)$ cytotoxic for colon cancer cells. Barranco and Eckhert (12) have shown that boric acid inhibits human prostate cancer cell proliferation by a mechanism that is not fully explained. Hacioglu et al. (13) also showed that boric acid inhibits dose-dependent cell growth in human prostate cancer cells, increases apoptosis and causes morphological changes. In 2004, GallardoWilliams et al. (14) reported that adding boron to the diet as a low dose reduces tumor size and expression of IGF-1, a tumor traffic factor, in subjects with human prostate adenocarcinoma. Korkmaz et al. (15) also showed that boron intake with drinking water decreased the frequency of histopathological signs associated with cervical cancer.

In this study, it was aimed to examine biological and possible anticancer effects of boron in vitro. For this purpose, the effect of various concentrations of boric acid on Caco- 2 colorectal adenocarcinoma cells was studied.

\section{Materials and Methods}

Chemical agents to be used in cell culture were supplied from Sigma-Aldrich (USA), while the necessary lab material was provided from Interlab (Turkey). Boric acid was purchased from Sigma-Aldrich (USA). Caco-2 colorectal adenocarcinoma cell line were used as cancer cells. Caco-2 cells were grown in high glucose Dulbecco's Modified Eagle's Medium (DMEM) supplemented supplemented with 10\% (v/v) fetal bovine serum (FBS) and $1 \%(\mathrm{v} / \mathrm{v})$ penicillinstreptomycin $(100 \mathrm{U} / \mathrm{mL}-100 \mu \mathrm{g} / \mathrm{mL})$ at $37{ }^{\circ} \mathrm{C}$ in a humidified atmosphere of $95 \%$ air and $5 \% \mathrm{CO}_{2}$ and were planted in 6 -well plates to be $1 \times 10^{5}$ cells/well to be $60-70 \%$ confluent. The concentration range for boric acid was selected by preliminary experiments conducted in our laboratory. Four different doses of boric acid $(0.1,0.25,0.5$ and $1 \mathrm{mM})$ were administered to the cells whose passages were made daily. Boric acid was not applied to the control group. The effect of boric acid on cancer cell proliferation was examined by hemocytometer at the end of 24 hours, 48 hours and 7 days. Cell viability was additionally studied with the Cell Titer-Glo Assay.

\section{Hemocytometric Measurement}

The media in the wells has been collected and 400 $\mu \mathrm{L}$ trypsin-EDTA solution was added to each well and the cells were kept at $37^{\circ} \mathrm{C}$ for 5 minutes. $1 \mathrm{~mL}$ of $10 \%$ FBS containing DMEM was added to neutralize the effect of trypsin. Cell suspensions were centrifuged at 3.000 RPM for 5 minutes and supernatant was discarded. $1 \mathrm{~mL}$ media was added to each tube, the cells were re-suspended. Cell counts were performed using a hemacytometer and trypan blue for identifying non-viable cells.

\section{Cell Titer-Glo Assay}

Cell Titer-Glo assay (Promega G7570, Southampton, UK) test were used to determine the changes in the number of living cells in the culture environment by measuring ATP formation in cells using the luminometric method. The cells were trypsinized, as indicated in the hemocytometric measurement above. Then, an equal volume (100 micrometers) of cell suspension was taken from each group and added to opaque plates with 96 wells. Cell Titer-Glo reagents were added to the wells at the ratio specified in the protocol. After the cells incubated in the orbital shaker for 2 minutes were kept at room temperature for 10 
minutes, luminescence in the wells was detected. The results were compared with hemocytometric evaluation of cells stained with Trypan blue by light microscopy.

\section{Western Blot and SDS PAGE Analysis}

The effect of boric acid on Caco-2 cells were determined with using the SDS PAGE and western blot method. Caco-2 cells were exposed to boric acid for 7 days at doses of $0.1,0.25,0.5$ and $1 \mathrm{mM}$. Following treatments, monolayer cells were washed with PBS (1.200 RPM 5 min). For protein extraction, pellets were submerged in lysis buffer $(250 \mathrm{mM} \mathrm{NaCl}$, 0.1\% NP40, 50 mM HEPES (pH 7.0), 5 mM EDTA, 1 mM DTT, $10 \%$ protease inhibitor mixture), sonicated, and incubated for $40 \mathrm{~min}$ at $41{ }^{\circ} \mathrm{C}$. $12 \%$ separating (SDSPAGE) gels were loaded with $30 \mathrm{mg}$ of protein per sample and separated for $30 \mathrm{~min}$ at $100 \mathrm{~V}$, followed by $1 \mathrm{~h}$ at $200 \mathrm{~V}$. Separated proteins were transferred to nitrocellulose membranes for $4 \mathrm{~h}$ at $40 \mathrm{~V}, 41 \mathrm{C}$. Membranes were blocked overnight (non-fat dry milk $4 \mathrm{~g}, 38 \mathrm{mM}$ Tris base, $125 \mathrm{mM} \mathrm{NaCl}$ 2.5, $100 \mathrm{~mL}$ tween 20, $\mathrm{dd}_{2} \mathrm{O} 100 \mathrm{~mL}$ ). Caspase-3 polyclonal antibody and beta-actin (for control) were used (Santa Cruz, CA). The 2-h Caspase-3 primary antibody exposure (1/200-1/800 dilution) was followed by a 10 min wash in PBS/tween $20(0.1 \%)$ and 1-h secondary anti-goat antibody exposure (1/1.000 dilution) was followed by washed 3 times in PBS/tween $20(0.1 \%)$ mixture for 10 minutes. Probed membranes were submerged in enhanced chemiluminescence detection reagent, wrapped in cellophane, and exposed to X-ray film. In addition, BCL-2 protein expression in Caco-2 cells exposed to boric acid for 7 days was similarly analyzed with Western blot using BCL-2 antibody and Betaactin (Santa Cruz, CA).

\section{Statistical Analysis}

SPSS 12.0 (USA) software was used for statistical evaluation. The Mann-Whitney $U$ test, a nonparametric test, was used to evaluate the effect of boric acid treatment on Caco-2 cancer cells. The results are given as mean value \pm standard error. Results with a value of $p<0.05$ were considered significant.

\section{Results}

In different concentrations in the light of literature $0.025,0.05,0.10,0.25,0.5,1,2$ and $5 \mathrm{mM}$ boric acid solutions were prepared. When preparing these solutions, boric acid was found to completely dissolve in aqueous solutions at room temperature. It has been determined that ambient temperature increases boric acid solubility. As a result of preliminary studies, no significant effect was determined on Caco-2 cells at low and high concentrations. In the study, boric acid concentrations of $0.1,0.25,0.5$ and $1 \mathrm{mM}$ were used in accordance with the literature (12).

Effect of Boric Acid on Caco-2 Cells in Cell Culture

The effect of boric acid concentrations on cumulative cell life for seven days is given in Figure 1. Caco-2 cells (control group) not treated with boric acid always showed a viability of about $90 \%$ at all-time points, and the cumulative viability is about $60 \%$ at the end of 7 days. Time-dependent boric acid dose effect was observed in Caco-2 cells treated with 0.1, 0.25, 0.5 and $1 \mathrm{mM}$ boric acid. The maximum decrease in cell viability due to concentration at the end of seven days was observed in cells treated with $1 \mathrm{mM}$ of boric acid. At the end of seven days, the proliferation of Caco- 2 cells was suppressed by $27.6 \%$ of boric acid at $0.1 \mathrm{mM}, 48.2 \%$ at $0.25 \mathrm{mM}, 52.4 \%$ at $0.5 \mathrm{mM}$, and $76.4 \%$ at $1 \mathrm{mM}$, respectively $(\mathrm{p}<0.05)$.

The effect of boric acid administration at four different concentrations $(0.1,0.25,0.5$ and $1 \mathrm{mM})$ on

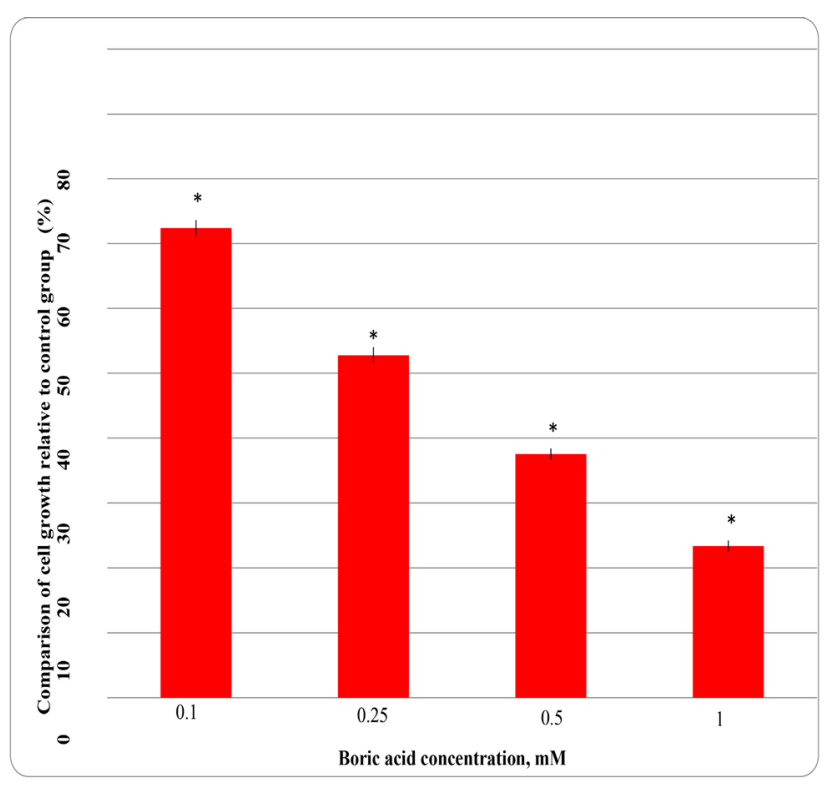

Figure 1. Dose dependent changes in colorectal cancer cell Caco-2 proliferation compared to control group cells not treated with boric acid. Boric acid (0-1 mM) was applied for 7 days. Data shows that the mean values in boric acid treatment groups compared with the mean values of control group $(p<0.05)$. The values are given as mean \pm standard error of six independent measurements 
the proliferation of Caco- 2 cells was studied. Figure 2 shows how cell growth changes during seven days in the presence and absence of $1 \mathrm{mM}$ of boric acid. 1 $\mathrm{mM}$ of boric acid led to a $46.6 \%$ inhibition in Caco-2 cells at the end of seven days. The first two days $1 \mathrm{mM}$ boric acid has no statistically significant effect on cell proliferation ( $p>0.05) .1 \mathrm{mM}$ of boric acid was found to statistically significant prevent the growth of Caco2 cells from the fourth day $(p<0.05)$.

Changes in the number of living cells in the cell viability were detected by measuring ATP formation in cells using the luminometric method using the Celltiter Glo assay. The data is normalized according to control with $100 \%$ cell viability. There is statistical significance between the control and boric acid treated groups $(p<0.05)$. The results given in Figure 3 were found to be similar to the values determined by hemocytometric method.

\section{Western Blot Assay}

Caspase-3 is an aspartame-specific cysteine protease expressed during apoptotic cell death and is used as an apoptosis marker. In shown in Figure 4, Caspase- 3 protein was not observed in Caco-2 cells that were treated with boric acid (0-1 mM) for 7 days in western blot analysis. Beta-actin ( $43 \mathrm{kDa}$ ) has been used as a control.

Changes in BCL-2 levels in boric acid-treated cells have been investigated. BCL-2 has protective effects against various stresses (chemotherapeutic agents, free oxygen radicals, etc) and are considered antiapoptotic marker. Also decrease in $\mathrm{BCL}-2$ protein

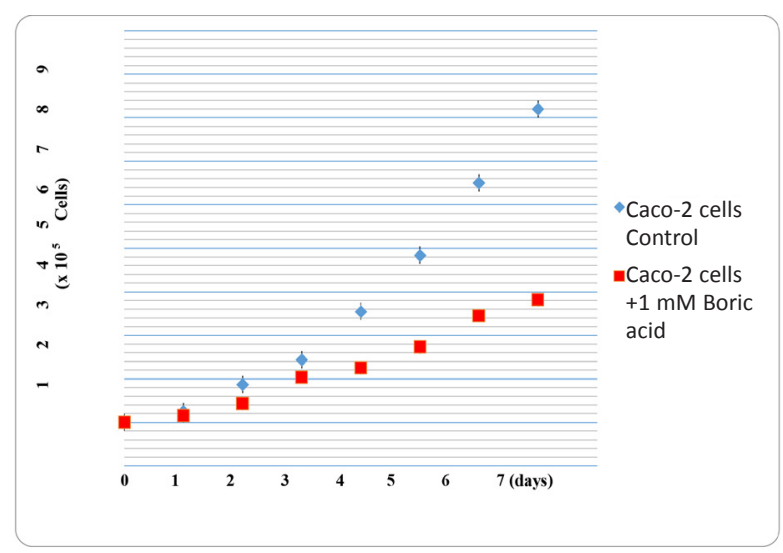

Figure 2. The growth of Caco-2 cells in the presence and absence of $1 \mathrm{mM}$ of boric acid (each point represents mean of six independent measurement \pm standard error) expression is observed as the concentration of boric acid increases in Caco- 2 cells exposed to boric acid for 7 days (Figure 5 ).

\section{Discussion}

There are publications that report that boric acid has a beneficial effect by preventing cancer cell proliferation. Albuz et al. (11) stated that boron oxide inhibits proliferation of DLD-1 colorectal adenocarcinoma cells. In their experiment, they used $20 \mu \mathrm{g} / \mathrm{mL}, 10 \mu \mathrm{g} / \mathrm{mL}, 5 \mu \mathrm{g} / \mathrm{mL}$, and $2.5 \mu \mathrm{g} / \mathrm{mL}$ of boron oxide concentrations and they demonstrated that

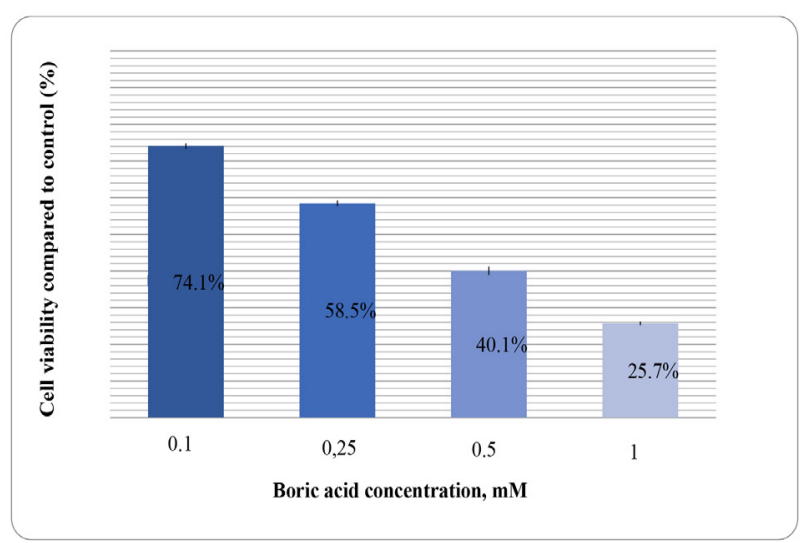

Figure 3. Effects of boric acid on the viability of Caco-2 cells with Cell Titer-Glo assay. The values are given as mean \pm standard error of six independent measurements

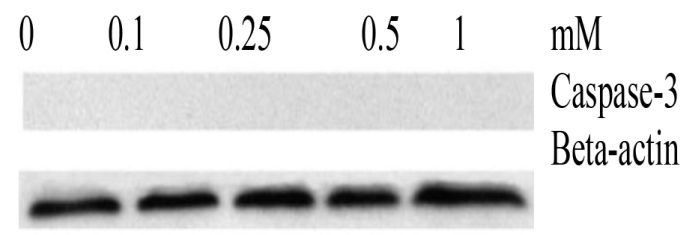

Figure 4. Caspase-3 protein expression by Western blot analysis in Caco- 2 cells exposed to boric acid for 7 days

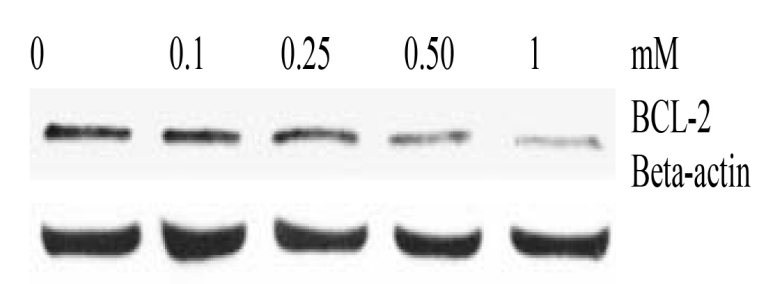

Figure 5. BCL-2 protein expression by Western blot analysis in Caco- 2 cells exposed to boric acid for 7 days 
boron oxide effective against cancer cells in a dose dependent fashion (11). Barranco and Eckhert (12) showed that boric acid inhibits proliferation of prostate cancer cells DU-145 and LNCaP in a dose dependent manner, while higher boric acid concentrations were needed to inhibit cell proliferation of non-tumorigenic prostate cell lines of PWR-1E, RWPE-1 and PC-3 cancer line (12). Hacioglu et al. (13) have showed that boric acid caused oxidative stress, inhibition of cell growth, apoptosis, and morphological alterations in a concentration-dependent manner in DU-145 prostate cancer cells. Gallardo-Williams et al. (14) stated that boric acid treatment reduced tumor development in nude mice that implanted with LNCaP, a human prostate cancer cell line (14).

Meacham et al. (16) reported that $1 \mathrm{mM}$ boric acid completely inhibits the proliferation of DU-145 prostate cancer cells, but does not affect growth rates of LNCaP and PC-3 cancer cells. In their study with breast cancer, Meacham et al. (16) showed that boric acid had no effect of proliferation of either estrogen receptor-negative (MDA-MB-231, MDAMB-435) or estrogen receptor-positive (MCF-7 and T47-D) breast cancer cell lines. On the other hand, they found that boric acid inhibits cell proliferation of estrogen negative (SK-BR-1) and positive (ZR-751) breast cancer cell lines and they concluded that estrogen does not contribute to the effect of reducing cell proliferation (16). Barranco and Eckhert (12) also reported that sex-related hormones do not effect inhibition of cell proliferation of boric acid on prostate cancer cells. In our study, we showed that boric acid inhibits colorectal cancer cells in dose dependent manner.

Boric acid has been reported to stimulate the release of stored $\mathrm{Ca}^{++}$from growing DU-145 prostate cancer cells while inhibiting $\mathrm{NAD}^{+}$and $\mathrm{NADP}^{+}$. In this study, they stated that $0.1 \mathrm{mM}$ boric acid inhibits $30 \%$, $0.25 \mathrm{mM}$ boric acid inhibits $60 \%$ and $1 \mathrm{mM}$ boric acid inhibits 97\% DU-145 cell proliferation (17). In our study, boric acid inhibited Caco-2 cell proliferation at $27.6 \%$ of $0.1 \mathrm{mM}, 48.2 \%$ of $0.25 \mathrm{mM}$ and $76.6 \%$ of 1 $\mathrm{mM}$ boric acid concentrations.

Barranco and Eckhert (12) reported that boric acid has no effect on caspase- 3 expression and adherens activity of DU-145 prostate cancer cells in Go phase, while they investigating the inhibitory mechanism of boric acid (12). On the other hand, Hacioglu et al. (13) have showed that boric acid caused oxidative stress, inhibition of cell growth, apoptosis, and morphological alterations in a concentration-dependent manner in DU-145 prostate cancer cells. They also showed that increase in caspase-3 expression in $10.77 \mathrm{mM}$, and $16.15 \mathrm{mM}$ boric acid concentrations (13). Our study also found no detectable caspase-3 expression or activity indicating apoptosis in Caco- 2 cells. These results suggest to us that boric acid stimulates apoptosis at higher treatment doses.

In 2006, Barranco and Eckhert (12) reported that boric acid treatment reduced MAPK and cyclin A-E levels in DU-145 prostate cancer cells while inhibiting cell proliferation. This effect was observed cells treated with boric acid 0.5 to $1 \mathrm{mM}$ for 7 days (18). No such effect was investigated in our study, but similar doses of boric acid were used. Decreased expression of proliferation-related proteins may play a role in the mechanism.

Acerbo and Miller (19) reported that boric acid administration led to a dose-dependent decrease in cell viability in human skin melanoma cells (SKMEL28), and as a result of Fourier transform infrared imaging studies, boric acid therapy did not lead to a change in lipid/protein ratio, but boric acid therapy made a significant decrease in nucleic acid/protein ratio. They reported that high doses of boric acid (12.5-50 mM) slowed cell replication and stimulated cell apoptosis by shift in the amide I Band (19).

Scorei et al. (20) they reported that boric acid and calcium fructoborate inhibit the growth of breast cancer cells on dose depended manner, but only calcium fructoborate stimulates apoptosis. They reported that although calcium fructoborate reduced the level of $\mathrm{p} 53$ and $\mathrm{BCL}-2$ proteins in MDA-MB-231 human breast cancer cells, on the other hand boric acid did not show such an effect. BCL-2 is a protein that inhibits apoptosis and protects cells from various stresses (21). BCL-2 expression in PC-3 cells treated with boric acid decreased at dose-dependent rates, but they also reported that reduced cell proliferation effect of boric acid was not due to BCL-2 pathway (10). In our study, reduced BCL-2 expression was observed depending on dose in Caco- 2 cells exposed to boric acid for 7 days. No findings on the mechanism have been observed. 


\section{Conclusion}

We showed that boric acid inhibited cell proliferation of colorectal adenocarcinoma cells in dose dependent fashion. To the best of our knowledge, this is the first study to show anti-cancer effects of boric acid against Caco-2 cancer cell line. Further studies using advanced molecular techniques are needed to explain the anti-cancer mechanism of boric acid. We believe that our results may establish a new alternative treatment regimen for colon cancer, which often affects men and women.

\section{Ethics}

Ethics Committee Approval: This study does not require ethics committee approval.

Informed Consent: The patient is not included in this study.

Peer-review: Internally and externally peerreviewed.

\section{Authorship Contributions}

Concept: M.D.B., R.O.E., Design: M.D.B., R.O.E., Supervision: M.D.B., R.O.E., Data Collection or Processing: M.D.B., A.C.., Analysis or Interpretation: A.Ç., M.D.B., R.O.E., Materials: M.D.B., Literature Search: A.Ç., M.D.B., Writing: A.Ç.

Conflict of Interest: No conflict of interest was declared by the authors.

Financial Disclosure: This study was supported by the grant Aydın Adnan Menderes University Research Foundation (grant no: TPF-1027).

\section{References}

1. Midgley R, Kerr D. Colorectal cancer. Lancet 1999; 353: 391-9.

2. Sugarbaker PH. Successful management of microscopic residual disease in large bowel cancer. Cancer Chemother Pharmacol 1999; 43 (Suppl): S15-25.

3. Argust P. Distribution of boron in the environment. Biol Trace Element Res 1998; 66: 131-43.

4. Price CJ, Strong PL, Murray FJ, Goldberg MM. Blood boron concentrations in preggnant rads fed boric acid throughout gestation. Repord Toxicol 1997; 11: 833-42.

5. Murray FJ. A comparative review of the pharmacokinetics of boric acid in rodents and humans. Biol Trace Element Res 1998; 66: 331-41.
6. Moseman RF. Chemical disposition of boron in animals and humans. Environ Health Perspect 1994; 102 (Suppl 7): 113-7.

7. Rowe $\mathrm{R}$, Eckhert $\mathrm{C}$. Boron is required for zebrafish embrogenesis. J Exp Biol 2004; 202: 21-9.

8. Kelly GS. Boron: a review of its nutritional interactions and therapeutic uses. Altern Med Rev 1997; 2: 48-56.

9. Hunt CD, Idso JP. Dietary boron as a physiological regulator of the normal inflammatory response: a review and current research progress. J Trace Elem Exp Med 1999; 12: 221-3.

10. Barranco WT, Hudak PF, Eckhert CD. Evaluation of ecological and in vitro effects of boron on prostate cancer risk (United States). Cancer Causes Control 2007; 18: 71-7.

11. Albuz Ö, Dülger D, Tunali BÇ, Aydin F, Yalçin S, Türk M. Effects of B2O3 (boron trioxide) on colon cancer cells: our first-step experience and in vitro results. Turk J Biol 2019; 43: 209-23.

12. Barranco WT, Eckhert CD. Boric acid inhibits human prostate cancer cell proliferation. Cancer Lett 2004; 216: 21-9.

13. Hacioglu C, Kar F, Kacar S, Sahinturk V, Kanbak G. High concentrations of boric acid trigger concentration-dependent oxidative stress, apoptotic pathways and morphological alterations in DU-145 human prostate cancer cell line. Biol Trace Elem Res 2020; 193: 400-9.

14. Gallardo-Williams MT, Chapin RE, King PE, Moser GJ, Goldsworthy $\mathrm{TL}$, Morrison JP, et al. Boron supplementation inhibits the growth and local expression of IGF-1 in human prostate adenocarcinoma (LNCaP) Tumors in nude mice. Toxicol Pathol 2004; 32: 73-8.

15. Korkmaz M, Uzgören E, Bakirdere S, Aydin F, Ataman OY. Effects of dietary boron on cervical cytopathology and on micronucleus frequency in exfoliated buccal cells. Environ Toxicol 2007; 22: 17-25.

16. Meacham SL, Elwell KE, Ziagler S, Carper SW. Boric acid inhibits cell growth in breast and prostate cancer cell lines. Advance in Plant and Animal Boron Nutrution. Xu F, Heiner E. Goldbach $\mathrm{HE}$, Bell RW, Brown PH, Fujiwara T, et al. editors. Switzerland: Spinger; 2007; 299-306.

17. Barranco WT, Kim DH, Stella Jr SL, Eckhert CD. Boric acid inhibits stored Ca2+ release in DU-145 prostate cancer cells. Cell Biol Toxicol 2009; 25: 309-20.

18. Barranco WT, Eckhert CD. Cellular changes in boric acid-treated DU-145 prostate cancer cells. Br J Cancer 2006; 94: 884-90.

19. Acerbo AS, Miller LM. Assessment of the chemical changes induced in human melanoma cells by boric acid treatment using infrared imaging. Analyst 2009; 134: 1669-74.

20. Scorei R, Ciubar R, Ciofrangeanu CM, Mitran V, Cimpean A, lordachescu D. Comparative effects of boric acid and calcium fructoborate on breast cancer cells. Biol Trace Elem Res 2008; 122: 197-205.

21. Rudner J, Jendrossek V, Belka C. New sights in the role of Bcl-2. $\mathrm{Bcl}-2$ and endoplasmic reticulum. Apoptosis 2002; 7: 441-7. 